Journal of Engineering and Applied Sciences 14 (5): 1668-1675, 2019

ISSN: 1816-949X

(C) Medwell Journals, 2019

\title{
Determinants of Student's Success in ABU Robocon: A Case of Lac Hong University
}

\author{
${ }^{1}$ Thanh-Lam Nguyen, ${ }^{1}$ Lam Thanh Hien, ${ }^{2} \mathrm{Ngo}$ Quang Huan and ${ }^{3} \mathrm{Pham}$ Xuan Giang \\ ${ }^{1}$ Lac Hong University, Dong Nai, Vietnam (VN) \\ ${ }^{2}$ University of Economics Ho Chi Minh City, Ho Chi Minh, Vietnam (VN) \\ ${ }^{3}$ Industrial University Ho Chi Minh City, Ho Chi Minh, Vietnam (VN)
}

\begin{abstract}
Participating in robotics competitions, including ABU Asia-Pacific Robot Contest (ABU Robocon), has been a preferred learning environment to identify and foster student's creative potentials and skills for high quality 21st century workforce. Lac Hong University (LHU) and its students have made special achievements in $\mathrm{ABU}$ Robocon. Therefore, this study aims at identifying the determinants of their success as a typical example, so that, we can have proper actions or strategies to motivate students in actively participating in technological challenges/competitions for their future success. Top key determinants identified in this study include: student's passion in robotics and in innovations; interest of school leaders, faculties and staffs in the field school supports for student's makerspace; collaboration among team members and experiences from previous teams, their practice/trials; preparedness for future careers and vision of the development in robotics and mechatronics domains.
\end{abstract}

$\underline{\text { Key words: Determinants, student's success, Lac Hong University, ABU Robocon, Vision, domains }}$

\section{INTRODUCTION}

Creating proper learning conditions and environment to identify and foster the creative potential of students is very important for every teacher and education institution (Eckhoff, 2011) because creativity has well been identified as one of the key skills required from 21st century workforce and it should be considered as a critical goal for relevant stakeholders in education systems (Chan and Yuen, 2014; Robinson, 2011; Wagner, 2014). Richardson and Mishra (2017) proposed a tool named "SCALE- Support for Creativity in a Learning Environment" to provide specific examples for the support of creativity. Students need to be creative to deal with complex problems happened in their careers and daily lives (Wagner, 2014). However, Beghetto (2010), Dababneh et al. (2010) and Plucker et al. (2004) pointed that the traditional teacher-led activities and uniform tasks constrained student's creativity. Hence, more and more efforts have been paid in changing traditional teaching approaches to a more active ones with student-centered environments, for examples, problem-based/project-based learning, cocreation and cooperation, role play, model making or learning atmospheres in which innovative ideas are appreciated and mistakes are an important part of their knowledge construction, etc., (Jindal-Snape et al., 2013; Chan and Yuen, 2014). Such environments significantly support student's creativity and provide them with better senses of own success, stronger intellectual ability, higher confidence, intensified resilience, boosted motivation and engagement and enhanced critical thinking and problem-solving skills (Beghetto and Kaufman, 2014; Jindal-Snape et al., 2013; Peppler and Solomou, 2011).

Among the above listed approaches, Problem-Based Learning (PBL) has well attracted special attention of numerous scholars (Gupta et al., 2017; Rovers et al., 2018) as they significantly shape students for their future professional life (Raghav et al., 2008). PBL is based on problems to be facilitated in small groups for their self-regulation and discussion towards targeted learning objectives (Barrows, 1996), thus, it has positive impacts on student's learning process in higher education curricula across the world (Davidson et al., 2014; Moust et al., 2005; Yew and Goh, 2016). PBL helps students to remember learning content longer (Strobel and Van Barneveld, 2009) have deeper learning and conceptual understanding (Berkson, 1993; Gijbels et al., 2005) and skill development (Dochy et al., 2003; Kasim, 1999; Vernon and Blake, 1993).

In the engineering technology domain, participating in robotics competitions is a preferred learning strategy in PBL approach (Behnke, 2006) because students will have more opportunities or challenges in the optimality and/or reliability of their robots in terms of design, build and operation to satisfy all specified requirements within

Corresponding Author: Thanh-Lam Nguyen, Lac Hong University, Dong Nai, Vietnam (VN) 
limited resources such as time, budget, space and manpower. In addition, it will also help students to effectively develop their interaction skills and knowledge from various industries involved in the robotics and automation sector. Practically, there are several robotics competitions annually held across the world to stimulate the enthusiasm of students in pursuing technological challenges in their field of study. Among them, ABU Asia-Pacific Robot Contest (ABU Robocon) held annually aims at cultivating passion and ability among young engineers for making and building things and developing their interpersonal exchange.

From our viewpoints, student success in a competition is important in encouraging others to follow. And it is significant to clearly know the factors affecting the success, so that, we can propose proper actions or strategies to motivate students in actively participating in technological challenges/competitions. Therefore, as a typical example, this study aims at identifying the determinants of the great success by the students in Lac Hong University (LHU) in ABU Robocon because LHU holds national champion title for 8 years, 2 Grand Prix $(2014,2017)$ and three 1st runner-ups (2010, 2012, 2013) of ABU Robocon (Anonymous, 2015, 2018).

\section{MATERIALS AND METHODS}

\section{Briefs about ABU Robocon and Lac Hong University} ABU Robocon: Officially known as the ABU Asia-Pacific Robot Contest, ABU Robocon has been sponsored by the Asia-Pacific region's federation of broadcasting organizations, the Asia-Pacific Broadcasting Union (ABU), since, 2002. The event is organized once a year in every August with the participation of teams from countries in the region. Annual competition theme is proposed by host country, thus, the wide variety of cultures from the different areas results in the appealing challenges to all participants. ABU Robocon always appreciates the creative solutions among students from different countries to the same problem proposed each year, hence, creative and imaginative thinking in designing optimal mechanisms and techniques is critical to the success of a team in the fierce contest.

Lac Hong University: Founded in 1997, LHU is the first private university located in Dong Nai Province of the Southern key economic zone of Vietnam. With the ferocious competition on the labor marketplace, Board of Rectors of LHU firmly believe that providing high quality human resources satisfying the practical needs from industries is the key for the survival and sustainable development of LHU. Therefore, besides making necessary investment in recruiting high quality faculties, upgrading the quality of facilities/equipment, providing convenient learning environment, etc., they have several educational activities to motivate student's learning. One of which is encouraging students to participate in ABU Robocon due to its positive impacts and benefits to the students. The utmost efforts of the student help LHU have a high position in the international contest.

Impacts of robotics competition: There are several benefits of robotics competitions in building student knowledge and interest as pointed by Akagi et al. (2015). According to the review by Eguchi (2016), robotics competitions provide participating students with several positive impacts in terms of: confidence in using technology, understanding of the role of science and technology in solving real-world problems, interests in pursuing degree/career in technical, math or science related field, understanding of the value of working in teams, Increased self-confidence, learning on physics, programming, mechanical engineering, electronics and science, skills of communication, team work and personal development. These positive impacts can be seen constantly across geographical or cultural differences.

Such activities have a wide impact on not only students but also high school pupils to stimulate their interests in robotics which can effectively help them to be innovative in finding optimal solutions to solve problems, thus, they can gain useful benefits for their project-based programmes (Barak and Zadok, 2009). Moreover, through the building of their robots, students in a team learn how to collaborate with each other in their discussions, solution proposals, knowledge sharing, etc., meaning that they can effectively foster their "team skills" (Varney et al., 2012; Sugimoto, 2011). Hence, participating in robotics competitions is a good chance for students to have a collaborative and practical learning experience (Chang et al., 2010; Hong et al., 2011).

Student success: According to Kinzie and Kuh (2016), the term "student success" can be understood from different aspects, thus, there are several different definitions and indicators to be considered in the literature, for example, student success can infer individual or group achievement levels, shortened "time to degree", degree completion and post-college employment and earnings, content knowledge gains, engagement in educational processes that foster a high-quality undergraduate experience and even student's personal success, etc. In this study, student success in ABU Robocon refers to the performance and achievement of students in the game as 
Table 1: Items used in official questionnaire

\begin{tabular}{|c|c|}
\hline Observed variables & Code \\
\hline Personal perspectives & $\mathbf{P}$ \\
\hline Personal passion in innovation & P01 \\
\hline Knowledge in robotics & $\mathrm{P} 02$ \\
\hline Personal passion in robotics & P03 \\
\hline $\begin{array}{l}\text { Vision of the future development } \\
\text { in robotics and mechatronics }\end{array}$ & $\mathrm{P} 04$ \\
\hline Preparedness for future career & P05 \\
\hline Initiative in implementing creative ideas & P06 \\
\hline Competence in analyzing problems & $\mathrm{P} 07$ \\
\hline Competence in identifying problems & P08 \\
\hline Competence in proposing feasible solutions & P09 \\
\hline Competence in critical thinking & P10 \\
\hline Competence in expressing ideas & P11 \\
\hline Competence in automation programming & P12 \\
\hline Competence in creating optimal mechanisms & P13 \\
\hline Other personal perspectives & P14 \\
\hline Organizational perspectives & OR \\
\hline Interest of LHU leaders & OR1 \\
\hline Interest of faculties and staffs in the field & OR2 \\
\hline $\begin{array}{l}\text { School support of material/facilities } \\
\text { for student's makerspace }\end{array}$ & OR3 \\
\hline $\begin{array}{l}\text { School support in having flexible } \\
\text { study schedule for those } \\
\text { participating in the competition }\end{array}$ & OR4 \\
\hline $\begin{array}{l}\text { School support in providing initial } \\
\text { financial aid for making prototype }\end{array}$ & OR5 \\
\hline $\begin{array}{l}\text { Adequate encouragement during the } \\
\text { student's practice and trials to } \\
\text { perfect their robots }\end{array}$ & OR6 \\
\hline Other organizational perspectives & OR7 \\
\hline Other perspectives & OT \\
\hline Collaboration among team members & OT1 \\
\hline Advances in science and technology & OT2 \\
\hline $\begin{array}{l}\text { Available equipment in automation } \\
\text { and control }\end{array}$ & OT3 \\
\hline $\begin{array}{l}\text { Cumulative experiences learnt } \\
\text { from previous teams }\end{array}$ & OT4 \\
\hline $\begin{array}{l}\text { Experiences learnt from practice } \\
\text { and trials with other teams }\end{array}$ & OT5 \\
\hline Competition among teams in the school & OT6 \\
\hline Competition with other teams from other schools & OT7 \\
\hline Expectation and encouragement from their family & OT8 \\
\hline Expectation and encouragement from their friends & OT9 \\
\hline
\end{tabular}

well as their career opportunities and income resulted from their achievement. As a matter of fact, LHU students from Robocon teams are usually employed by prestigious companies with a highly-paid salary even before they graduate from their study programs.

Kuh et al. (2006) pointed that student success includes several perspectives, including: sociological, organizational, cultural, psychological and economic. According to the discovery of Sorensen (2016), the success of a $\mathrm{PhD}$ candidate is affected by some factors, including: interest, incentive, idea, initiative, integrity and interpersonal relationships whereas the success of a postdoctoral one is usually determined by identity, independence and image, implementation, innovative and important topics, in-depth knowledge, interactive and integrated with research community and internationally oriented.
Research method: Based on literature reviews, we classify the determinants of the student's success into three categories, including: personal factors, organizational factors and others. We developed relevant measures for each scale in a self-completed questionnaire designed on 5-Likert scale about the level of impacts of each specified item on the success of LHU students in $\mathrm{ABU}$ Robocon over the past few years. We first conducted qualitative research and pilot test before producing our final version. Table 1 briefly shows the items and their respective coded names used in our official questionnaire.

Then, we created online version, so that, we can have more participants in our official survey. Our target participants include: LHU Leaders including Rector, Vice Rectors, Deans and Deputy Deans (denoted by LEAD); Faculties who are in or relate to Information Technology (IT) discipline and Mechatronics discipline (denoted by FIM); Faculties who are in other Disciplines (denoted by FOD); Team Members (denoted by MEM); Students studying IT discipline or Mechatronics discipline (denoted by SIM); Students studying other Disciplines (denoted by SOD); Student's Parents (denoted by STP); and Others from the listed positions (denoted by OTH). Relevant positions from other universities are also included in our official survey which was conducted in July 2018. In this study, we only used descriptive statistics to analyze the collected data.

\section{RESULTS AND DISCUSSION}

There were 502 completed questionnaires collected in hard copies and online; among them, there were 54 invalid observations due to several missing values. Consequently, 448 valid observations are used in this data analysis.

Participant positions: Figure 1 briefly shows the percentage of each type of positions investigated. Among the 448 valid observations, team members account for about $26 \%$ and students studying IT discipline or mechatronics account for more than $35 \%$. That FIM, SIM and MEM account for more than $70 \%$ of the total valid observations is critical in this study because they can provide reliable evaluations for the examined perspectives.

Descriptive statistics: Table 2 clearly shows that the evaluation of each investigated item is affected by the role and viewpoints of the participant. Based on the Variation Coefficients "VC", it can be concluded that there is significant difference in the evaluation of P01, P03, P04, 
Table 2: Descriptive statistics of surveyed items according to positions

\begin{tabular}{|c|c|c|c|c|c|c|c|c|c|c|c|}
\hline \multirow[b]{2}{*}{ Items } & \multicolumn{11}{|c|}{ Positions } \\
\hline & LEAD & FIM & FOD & MEM & SIM & SOD & STP & OTH & Mean & $\mathrm{SD}^{*}$ & $\mathrm{VC}^{* k * k}(\%)$ \\
\hline P01 & 4.17 & 4.17 & 4.13 & 4.65 & 4.27 & 4.85 & 4.11 & 4.16 & 4.40 & 0.76 & 17.27 \\
\hline $\mathrm{P} 02$ & 3.44 & 3.44 & 3.58 & 3.43 & 3.50 & 3.60 & 3.44 & 3.60 & 3.50 & 0.36 & 10.29 \\
\hline P03 & 4.17 & 4.10 & 4.19 & 4.92 & 4.56 & 4.19 & 4.22 & 4.16 & 4.50 & 0.92 & 20.44 \\
\hline P04 & 4.11 & 4.29 & 4.13 & 4.81 & 4.19 & 4.11 & 3.78 & 3.80 & 4.31 & 0.52 & 12.06 \\
\hline P05 & 4.72 & 4.66 & 4.61 & 4.72 & 4.08 & 3.85 & 3.78 & 3.92 & 4.32 & 0.40 & 9.260 \\
\hline P06 & 4.06 & 3.93 & 3.94 & 3.97 & 4.04 & 4.04 & 4.22 & 4.08 & 4.01 & 0.36 & 8.980 \\
\hline P07 & 3.89 & 3.88 & 3.90 & 3.88 & 3.89 & 3.94 & 3.89 & 3.92 & 3.89 & 0.40 & 10.28 \\
\hline P08 & 3.72 & 3.83 & 3.87 & 3.78 & 3.72 & 3.77 & 3.78 & 3.80 & 3.77 & 0.40 & 10.61 \\
\hline P09 & 3.89 & 3.73 & 3.97 & 3.79 & 3.76 & 3.77 & 4.11 & 3.76 & 3.79 & 0.39 & 10.29 \\
\hline P10 & 3.56 & 3.73 & 3.74 & 3.66 & 3.68 & 3.77 & 3.89 & 3.52 & 3.68 & 0.37 & 10.05 \\
\hline P11 & 4.06 & 3.93 & 4.03 & 3.95 & 3.99 & 3.96 & 4.00 & 3.92 & 3.97 & 0.32 & 8.060 \\
\hline $\mathrm{P} 12$ & 3.94 & 3.90 & 4.03 & 3.97 & 4.01 & 3.96 & 3.89 & 4.00 & 3.98 & 0.38 & 9.550 \\
\hline P13 & 3.83 & 3.83 & 3.84 & 3.79 & 3.81 & 3.79 & 4.11 & 3.84 & 3.82 & 0.38 & 9.950 \\
\hline P14 & 3.50 & 3.07 & 3.26 & 3.35 & 3.36 & 3.34 & 3.22 & 3.20 & 3.32 & 0.48 & 14.46 \\
\hline OR1 & 3.67 & 4.12 & 4.13 & 4.45 & 4.52 & 4.32 & 4.33 & 4.52 & 4.38 & 0.43 & 9.820 \\
\hline OR2 & 4.28 & 4.44 & 4.45 & 4.39 & 4.38 & 4.36 & 4.56 & 4.32 & 4.39 & 0.39 & 8.880 \\
\hline OR3 & 4.39 & 4.71 & 4.32 & 4.26 & 4.32 & 4.15 & 4.11 & 5.00 & 4.36 & 0.97 & 22.25 \\
\hline OR4 & 4.06 & 3.95 & 4.10 & 4.08 & 4.13 & 4.13 & 4.22 & 4.12 & 4.09 & 0.38 & 9.290 \\
\hline OR5 & 4.39 & 4.24 & 4.32 & 4.25 & 4.23 & 4.32 & 4.22 & 5.00 & 4.30 & 1.05 & 24.42 \\
\hline OR6 & 4.22 & 4.39 & 4.32 & 4.29 & 4.28 & 4.28 & 4.33 & 4.28 & 4.30 & 0.38 & 8.840 \\
\hline OR7 & 3.39 & 3.66 & 3.74 & 3.66 & 3.67 & 3.36 & 3.89 & 3.68 & 3.63 & 0.53 & 14.60 \\
\hline OT1 & 4.39 & 4.32 & 4.35 & 4.36 & 4.29 & 4.45 & 4.44 & 4.40 & 4.35 & 0.38 & 8.740 \\
\hline OT2 & 4.28 & 4.22 & 4.26 & 4.32 & 4.34 & 4.36 & 4.22 & 4.32 & 4.30 & 0.39 & 9.050 \\
\hline OT3 & 4.33 & 4.44 & 4.35 & 4.34 & 4.05 & 4.26 & 4.67 & 4.36 & 4.24 & 0.42 & 9.910 \\
\hline OT4 & 4.22 & 4.29 & 4.32 & 4.58 & 4.22 & 4.28 & 4.22 & 4.36 & 4.34 & 0.41 & 9.450 \\
\hline OT5 & 4.17 & 4.24 & 4.23 & 4.56 & 4.25 & 4.23 & 4.33 & 4.40 & 4.33 & 0.38 & 8.780 \\
\hline OT6 & 4.17 & 4.12 & 4.16 & 4.14 & 4.20 & 4.15 & 4.11 & 4.08 & 4.16 & 0.37 & 8.890 \\
\hline OT7 & 4.17 & 4.37 & 4.19 & 4.16 & 4.19 & 4.19 & 4.33 & 4.28 & 4.20 & 0.39 & 9.290 \\
\hline OT8 & 4.06 & 4.22 & 4.16 & 4.04 & 3.97 & 4.04 & 4.89 & 3.96 & 4.05 & 0.49 & 12.10 \\
\hline OT9 & 3.94 & 4.05 & 4.06 & 4.03 & 4.10 & 4.09 & 4.22 & 4.16 & 4.07 & 0.39 & 9.580 \\
\hline
\end{tabular}

*Standard deviation; **Variation Coefficient (VC = SD/Mean)

Table 3: Results of one-way ANOVA analysis

\begin{tabular}{|c|c|c|c|c|c|}
\hline Investigated items & Sum of squares & $\mathrm{df}$ & Mean square & F-values & Sig. \\
\hline \multicolumn{6}{|c|}{ Personal passion in innovation } \\
\hline Between groups & 26.881 & 7 & 3.840 & \multirow[t]{3}{*}{19.586} & \multirow[t]{3}{*}{0.000} \\
\hline Within groups & 85.875 & 438 & 0.196 & & \\
\hline Total & 112.756 & 445 & & & \\
\hline \multicolumn{6}{|c|}{ Personal passion in robotics } \\
\hline Between groups & 40.873 & 7 & 5.839 & \multirow[t]{3}{*}{30.953} & \multirow[t]{3}{*}{0.000} \\
\hline Within groups & 82.625 & 438 & 0.189 & & \\
\hline Total & 123.498 & 445 & & & \\
\hline \multicolumn{6}{|c|}{ Vision of the future development in robotics } \\
\hline Between groups & 44.114 & 7 & 6.302 & \multirow{3}{*}{35.415} & \multirow{3}{*}{0.000} \\
\hline Within groups & 77.940 & 438 & 0.178 & & \\
\hline Total & 122.054 & 445 & & & \\
\hline \multicolumn{6}{|c|}{ Preparedness for future career } \\
\hline Between groups & 54.419 & 7 & 7.774 & \multirow[t]{3}{*}{30.110} & \multirow[t]{3}{*}{0.000} \\
\hline Within groups & 113.088 & 438 & 0.258 & & \\
\hline Total & 167.507 & 445 & & & \\
\hline \multicolumn{6}{|c|}{ Inter est of LHU leaders } \\
\hline Between groups & 18.272 & 7 & 2.610 & \multirow[t]{3}{*}{10.519} & \multirow[t]{3}{*}{0.000} \\
\hline Within groups & 108.689 & 438 & 0.248 & & \\
\hline Total & 126.962 & 445 & & & \\
\hline \multicolumn{6}{|c|}{ School support of material/facilities for student's makerspace } \\
\hline Between groups & 19.332 & 7 & 2.762 & \multirow[t]{3}{*}{14.186} & \multirow[t]{3}{*}{0.000} \\
\hline Within groups & 85.269 & 438 & 0.195 & & \\
\hline Total & 104.601 & 445 & & & \\
\hline \multicolumn{6}{|c|}{ School support in providing initial financial aid for making prototype } \\
\hline Between groups & 13.616 & 7 & 1.945 & \multirow[t]{3}{*}{7.850} & \multirow[t]{3}{*}{0.000} \\
\hline Within groups & 108.521 & 438 & 0.248 & & \\
\hline Total & 122.137 & 445 & & & \\
\hline \multicolumn{6}{|c|}{ Available equipment in automation and control } \\
\hline Between groups & 10.985 & 7 & 1.569 & \multirow[t]{3}{*}{6.171} & \multirow[t]{3}{*}{0.000} \\
\hline Within groups & 111.376 & 438 & 0.254 & & \\
\hline Total & 122.361 & 445 & & & \\
\hline \multicolumn{6}{|c|}{ Cumulative experiences learnt from previous teams } \\
\hline Between groups & 9.507 & 7 & 1.358 & \multirow[t]{2}{*}{5.682} & \multirow[t]{2}{*}{0.000} \\
\hline Within groups & 104.690 & 438 & 0.239 & & \\
\hline
\end{tabular}


Table 3: Continue

\begin{tabular}{|c|c|c|c|c|c|}
\hline Investigated items & Sum of squares & df & Mean square & F-values & Sig. \\
\hline Total & 114.197 & 445 & & & \\
\hline \multicolumn{6}{|c|}{ Experiences learnt from practice and trials with other teams } \\
\hline Between groups & 8.801 & 7 & 1.257 & 5.959 & 0.000 \\
\hline Within groups & 92.421 & 438 & 0.211 & & \\
\hline Total & 101.222 & 445 & & & \\
\hline \multicolumn{6}{|c|}{ Expectation and encouragement from their family } \\
\hline Between groups & 9.155 & 7 & 1.308 & 5.995 & 0.000 \\
\hline Within groups & 95.553 & 438 & 0.218 & & \\
\hline Total & 104.709 & 445 & & & \\
\hline
\end{tabular}

Table 4: Different evaluation between positions in each detected item

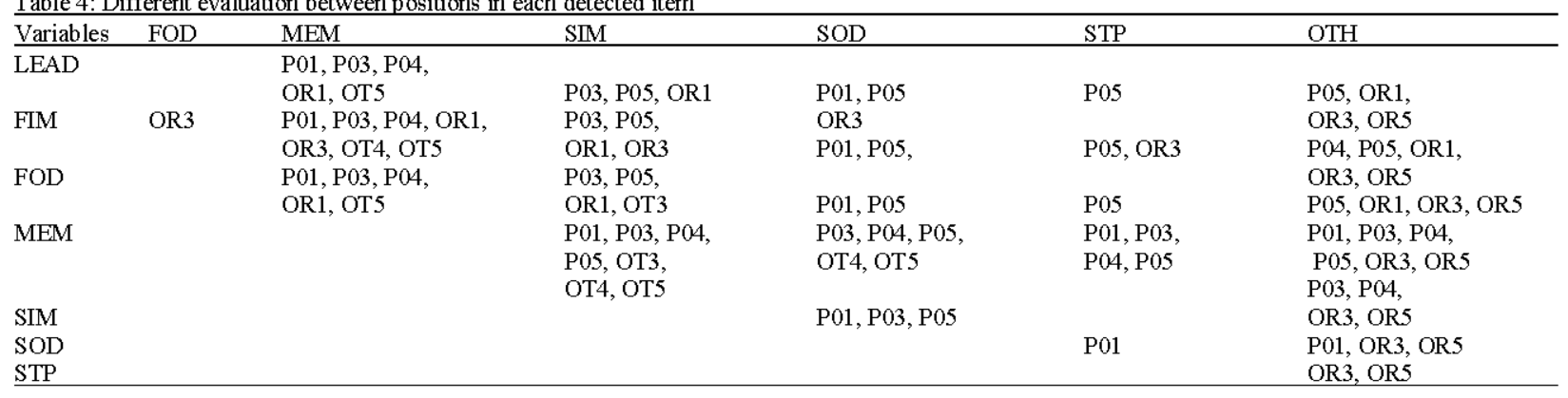

Table 5: Top 10 determinants of student's success in ABU Robocon

Determinants Rank

P03-Personal passion in robotics

P01-Personal passion in innovation

OR2-Interest of faculties and staffs in the field

OR1-Interest of LHU Leaders

OR3-School support of material/facilities for student's makerspace

OT1-Collaboration among team members

OT4-Cumulative experiences learnt from previous teams

OT5-Experiences learnt from practice and trials with other teams

P05-Preparedness for future career

P04-Vision of the future development in robotics and mechatronics

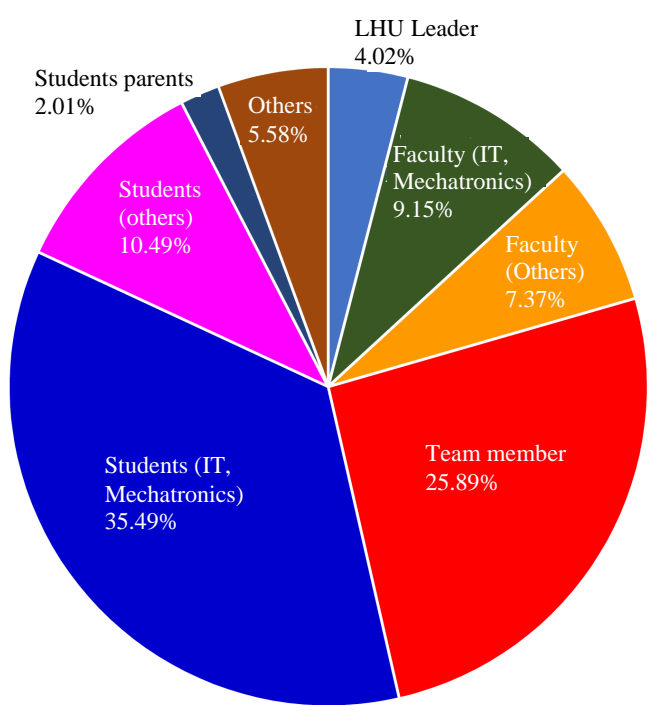

Fig. 1: Participant positions

OR3, OR5 and OT8 among the positions. To have a deeper understanding of the impacts of the positions on their evaluations, we conduct one-way ANOVA analysis whose results are shown in Table 3 . Through the analysis, we found that there are 11 out of the 30 items to have such significant difference; particularly, P01, P03, P04, P05, OR1, OR3, OR5, OT3, OT4, OT5 and OT8. More importantly, by using post-hoc testing we explicitly identify which position evaluates differently from which position under which item as briefly demonstrated in Table 4.

From the results in Table 4, we need to move a further step to examine root causes of such different in their evaluations, so that, LHU can have proper actions or strategies to well attract its students to actively participate in technological challenges/ competitions for their learning and success. Moreover, from the mean values in column "MEAN" of Table 2, we can sort out top ten determinants of the student's success in ABU Robocon based on their impact levels shown in Table 5.

The great success in $\mathrm{ABU}$ Robocon in the case of LHU and its students over the last decade is resulted from 
various perspectives such as student's personal characteristics, team-work, encouraging support from their school and faculties, etc. Specifically, the personal passion in robotics and general innovations are two of the most important factors affecting their success because the passion helps to propel persistence, concentration and full engagement in making their robots. Our finding in the role of passion further agrees with those by Bonneville-Roussy et al. (2013), Ruiz-Alfonso and Leon (2016) and Ruiz-Alfonso et al. (2018). Moreover, such passion is critical for their deliberate practice and motivation to improve their robot performance through the learning-by-doing process. Therefore, passion is one of the key personal characteristics for the success in practice, meaning that inspiring student's interest in science and fostering their passion should be fully considered as the key role of a teacher in the $21 \mathrm{st}$ century.

In addition, the interest of the leaders, faculties/staffs in the ABU Robocon and their supports for student's makerspace are also the key determinants of the success. In preparing for their robots, students need professional advice and guidance from the faculties/staffs in the related fields. The interest in the field assures the faculties/staffs to be more active in offering their students with valuable comments and suggestions to improve their robots and it also helps the leaders to provide enough supports in terms of makerspace and flexible study schedule, so that, the students can stay focused in building their robots. Such supports from the leaders, relevant faculties/staffs help passionate students be more proactive in implementing their creative ideas/solutions.

Moreover, the student's success in ABU Robocon is significantly determined by the collaboration among team members, cumulative experiences learnt from previous teams from practice and trials with other teams. As working in team all members need to effectively collaborate to achieve their common goals in creating optimal performance for their robots, meaning that the students have the opportunity to develop their teamwork skill. Learning from previous and self-experiences is a good learning strategy frequently used in studentcentered education philosophy. Therefore, this implies that teachers in an education program need to promote a good interactive, cooperative and sharing atmosphere among students as well as alumni.

Last but not least, previous students participating in ABU Robocon were able to easily find good jobs with highly-paid salaries and high positions right after their graduation or several industrial companies get to LHU to directly contract with students who were in quarter-finals, semi-finals and finals, especially, those won champion titles. Such good opportunities urge more students to join the robotics teams and try to do their best, so that, they can learn more from the problems specified in the theme by the host country. These experiences help them well prepare for their future careers in the industrial fields, especially in robotics and mechatronics domain. That explains why this study finds "preparedness for future career" and "vision of the future development in robotics" as two key determinants of the student's success in ABU Robocon. This implies that key benefits in participating in a project should be well emphasized and promoted as incentives for fostering student's potentials, passions and success.

\section{CONCLUSION}

The great success of LHU and its students in ABU Robocon over the past decade is significantly affected by several factors. Among them, top key determinants identified in this study include: student's passion in robotics and in innovations; interest of school leaders, faculties and staffs in the field; school supports for students' makerspace; collaboration among team members and experiences from previous teams, their practice/trials; preparedness for future careers and vision of the development in robotics and mechatronics domains. These findings are important to have proper actions or strategies to motivate students in actively participating in technological challenges/competitions for their future success.

\section{REFERENCES}

Akagi, T., S. Fujimoto, H. Kuno, K. Araki and S. Yamada et al., 2015. Systematic educational program for robotics and mechatronics engineering in OUS using robot competition. Procedia Comput. Sci., 76: 2-8.

Anonymous, 2015. Development process: Key dates of LHU. LHU-Lac Hong University, Bien Hoa, Vietnam.

Anonymous, 2018. Robot competitions. Robotics Education and Competition Foundation. Greenville, Texas.

Barak, M. and Y. Zadok, 2009. Robotics projects and learning concepts in science, technology and problem solving. Intl. J. Technol. Des. Educ., 19: 289-307.

Barrows, H.S., 1996. Problem-Based Learning in Medicine and Beyond: A Brief Overview. In: Bringing Problem-Based Learning to Higher Education: Theory and Practice, Wilkerson, L. and W.H. Gijselaers (Eds.). Wiley Publisher, Hoboken, New Jersey, USA., ISBN:9780787999346, pp: 3-12.

Beghetto, R., 2010. Creativity in the Classroom. In: The Cambridge Handbook of Creativity, Kaufman, J.C. and ?R.J. Sternberg (Eds.). Cambridge University Press, Cambridge, New York, UK., ISBN:978-0-521-51366-1, pp: 447-459. 
Beghetto, R.A. and J.C. Kaufman, 2014. Classroom contexts for creativity. High Ability Stud., 25: 53-69.

Behnke, S., 2006. Robot competitions-ideal benchmarks for robotics research. Proceedings of the International Workshop on Benchmarks in Robotics Research IROS-2006, October, 9-15, 2006, IEEE, Beijing, China, pp: 1-5.

Berkson, L., 1993. Problem-based learning: Have the expectations been met?. Acad. Med., 68: 79-88.

Bonneville-Roussy, A., R.J. Vallerand and T. Bouffard, 2013. The roles of autonomy support and harmonious and obsessive passions in educational persistence. Lear. Individual Differences, 24: 22-31.

Chan, S. and M. Yuen, 2014. Personal and environmental factors affecting teachers creativity-fostering practices in Hong Kong. Thinking Skills Creativity, 12: $69-77$.

Chang, C.W., J.H. Lee, P.Y. Chao and C.Y. Wang et al., 2010. Exploring the possibility of using humanoid robots as instructional tools for teaching a second language in primary school. J. Educ. Technol. Soc., 13: 13-24.

Dababneh, K., F.M. Ihmeideh and A.A. Al-Omari, 2010. Promoting kindergarten childrens creativity in the classroom environment in Jordan. Early Child Dev. Care, 180: 1165-1184.

Davidson, N., C.H. Major and L.K. Michaelsen, 2014. Small-group learning in higher educationcooperative, collaborative, problem-based and teambased learning: An introduction by the guest editors. J. Excellence Coll. Teach., 25: 1-6.

Dochy, F., M. Segers, P. Van Den Bossche and D. Gijbels, 2003. Effects of problem-based learning: A meta-analysis. Lear. Instruction, 13: 533-568.

Eckhoff, A., 2011. Creativity in the early childhood classroom: Perspectives of preservice teachers. J. Early Childhood Teach. Edu., 32: 240-255.

Eguchi, A., 2016. Robocup junior for promoting STEM education, 21st century skills and technological advancement through robotics competition. Rob. Auton. Sys., 75: 692-699.

Gijbels, D., F. Dochy, Van den P. Bossche and M. Segers, 2005. Effects of problem-based learning: A meta-analysis from the angle of assessment. Rev. Edu. Res., 75: 27-61.

Gupta, V., R. Patel, G. Sardal, J. Ray and S.K. Saha et al., 2017. Design and development of robots for ABU robocon 2016. Proceedings of the International Conference on Advances in Robotics (AIR'17), June 28-July 02, 2017, ACM, New York, USA., ISBN:978-1-4503-5294-9, pp: 1-13.
Hong, J.C., K.C. Yu and M.Y. Chen, 2011. Collaborative learning in technological project design. Intl. J. Technol. Des. Edu., 21: 335-347.

Jindal-Snape, D., D. Davies, C. Collier, A. Howe and R. Digby et al., 2013. The impact of creative learning environments on learners: A systematic literature review. Improving School., 16: 21-31.

Kasim, R.M., 1999. What can studies of problem-based learning tell us? Synthesizing and modeling PBL effects on national board of medical examination performance: Hierarchical linear modeling meta-analytic approach. Adv. Health Sci. Edu., 4: 209-221.

Kinzie, J. and G. Kuh, 2016. Review of student success frameworks to mobilize higher education. Master Thesis, Lumina Foundation, Indiana, USA.

Kuh, G.D., J.L. Kinzie, J.A. Buckley, B.K. Bridges and J.C. Hayek, 2006. What Matters to Student Success: A Review of the Literature. Vol. 8, National Postsecondary Education Cooperative, Washington, DC, USA., Pages: 302.

Moust, J.H., H.V. Berkel and H.G. Schmidt, 2005. Signs of erosion: Reflections on three decades of problem-based learning at Maastricht University. Higher Educ., 50: 665-683.

Peppler, K.A. and M. Solomou, 2011. Building creativity: Collaborative learning and creativity in social media environments. Horiz., 19: 13-23.

Plucker, J.A., R.A. Beghetto and G.T. Dow, 2004. Why isnt creativity more important to educational psychologists? Potentials, pitfalls and future directions in creativity research. Educ. Psychol., 39: 83-96.

Raghav, M.S., S. Jain and S.K. Saha, 2008. Robotic competition based education in engineering. Proceedings of the International Conference on Mechanism Science and Technology (NCMSTA'08), November 13-14, 2008, National Institute of Technology, Hamirpur, India, pp: 1-11.

Richardson, C. and P. Mishra, 2017. Learning environments that support student creativity: Developing the scale. Thinking Skills Creativity, 27: 45-54.

Robinson, K., 2011. Out of our Minds: Learning to be Creative. Capstone Publishing, Mankato, Minnesota, USA., ISBN:1907312471, Pages: 326.

Rovers, S.F., G. Clarebout, H.H. Savelberg and V.J.J. Merrienboer, 2018. Improving student expectations of learning in a problem-based environment. Comput. Hum. Behav., 87: 416-423. 
Ruiz-Alfonso, Z. and J. Leon, 2016. The role of passion in education: A systematic review. Educ. Res. Rev., 19: 173-188.

Ruiz-Alfonso, Z., L.S. Vega and E.V. Beltran, 2018. What about passion in education? The concept of passion, why it is important and how teachers can promote it. Eur. Sci. J., 14: 19-28.

Sorensen, H.T., 2016. I-determinants for a successful $\mathrm{PhD}$ or postdoctoral outcome. Clin. Epidemiol., 8: 297-303.

Strobel, J. and A. Van Barneveld, 2009. When is PBL more effective? A meta-synthesis of meta-analyses comparing $\mathrm{PBL}$ to conventional classrooms. Interdiscip. J. Prob. Based Lear., 3: 44-58.

Sugimoto, M., 2011. A mobile mixed-reality environment for childrens storytelling using a handheld projector and a robot. IEEE. Trans. Lear. Technol., 4: 249-260.
Varney, M.W., A. Janoudi, D.M. Aslam and D. Graham, 2012. Building young engineers: TASEM for third graders in woodcreek magnet elementary school. IEEE. Trans. Educ., 55: 78-82.

Vernon, D.T. and R.L. Blake, 1993. Does problem-based learning work? A meta-analysis of evaluative research. Acad. Med., 68: 550-563.

Wagner, T., 2014. The Global Achievement Gap: Why Even our Best Schools don't Teach the new Survival Skills our Children Need and what we can do About it. Basic Books, New York City, New York, USA., ISBN:9780465055968, Pages: 360.

Yew, E.H. and K. Goh, 2016. Problem-based learning: An overview of its process and impact on learning. Health Prof. Edu., 2: 75-79. 